\title{
Overview of Additional Issue of Shares and Debt In The Process of Value Appraisal of Shares and Planning of Additional Issue Parameters
}

\author{
Yuriy V. Kozyr \\ Department of Theoretical Economy and Mathematic Research, Central Economics and \\ Mathematics Institute of Russian Academy of Sciences, Moscow, Russia.
}

\begin{abstract}
The article contains a theoretical analysis of the impact of additional issue of shares on the value of the invested and stock capital. The present analysis encompasses aspects of redistribution of capital between the old and new shareholders, as well as valuation procedures in different situations, both in terms of the volume of additional issue of shares and of payment methods. The income approach is used in the value appraisal. The principal place under the income approach is given to the shareholder value added model (model SVA). This article may be useful in solving a number of practical problems related to the issues of restructuring of the company's capital. Investment analysts will find in this article a tool of benefit-sharing analysis of the capital structure changes between "old" and "new" company's shareholders and will be able to make a calculation of the parameters of the additional issue of shares.

GEL classification numbers: D 460, G 120, G 320.
\end{abstract}

KeyWords: Additional issue of shares (SPO), value of shares prior to the additional issues, value of shares after additional issues, share in the company's capital.

\section{INTRODUCTION}

In 2006 the author of the present article attended a seminar in Moscow conducted by a wellrecognized in the evaluation world Guru. A seminar attendee asked the spokesman: "How should the shares be valued, when an additional issue of shares takes place?", and the Guru replied: "I don't know." It must be noted that this question bothered me even before the seminar, but after the seminar I got down to it more closely and within a couple of months managed to obtain the first results (Kozyr, 2007). However, afterwards some routine affairs kept me away from this topic for a whole decade until I finally attempted to reconsider the obtained results, systematize them and present them in a more comprehensible way. While working on this question I came upon some new ideas, which made me extend the scope of my research. The attempt to study the background of the problem became a special challenge for me. I cannot state that there is nothing on this topic - of course there is. Nevertheless, the valuation of shares during the additional issue thereof cannot be considered a well-studied subject. The majority of publications on this topic touch upon the questions of recapitalization accounting in the cost of capital assessment. The author found just one work (Brealey, Myers, 2004) that covered the aspects of valuation related to the additional issue of shares. Let us take a closer look at these aspects in the way they were presented in this work.

When the share issue takes place, the existing company shares can be evaluated in two ways. The first is to discount the net cash flow that is received by the current shareholders, if they buy all of the newly issued shares. In this case the shareholders supply the issuing company 
with money [for example, in the periods when negative cash flow balance is expected - note by Yu.K.] and then receive all subsequent dividends, which means they pay for and receive the whole free cash flow in all future periods. Consequently, the share price equals to the gross free cash flow of the company's shareholders, including both negative and positive values, divided by the amount of the existing shares.

The second way is to discount the amount of dividends subject to payout once the cash flow is positive. But in this case the only dividends that should be taken into account are those paid on the existing shares. The new shares issued to finance the negative free cash flow in the forecast period also claim part of future dividends.

Both introduced shares valuation methods should give the same result. It should be noted that under these approaches the amount of new (issued) shares is to be defined as the quotient of the funds raised as a result of additional issue and the market value of a single share ${ }^{1}$. It should also be noted that the net present value of investments of the new shareholders buying the issued shares should amount to zero, i.e. the purchase price for them should equal to the expected net income flow from their shares.

The two stipulated methods can be applied to the situation, when a company uses its free cash flow for redemption of its own shares. In such cases several important issues should be taken into account. Firstly, all other conditions being equal the value of the company does not depend on the decision to replace cash dividends with redemption of shares. Secondly, when evaluating the equity value both cash distributed as dividends and cash intended for redemption of shares should be considered. Thirdly, inclusion of both the expected dividends per share and the funds received by the shareholders from share redemption when calculating the cash flow per share would mean double count (if you sold your share back to the company, you would receive no dividends in the future). Fourthly, the company redeeming its shares instead of paying out dividends reduces the amount of shares in circulation, but compensates it by raising earnings and dividends per share.

As stated above, there are many publications on the influence of recapitalization on the fund raising costs. These include the following publications and evaluation methods.

One way of evaluation during the recapitalization is the method offered by R. Brealey and S. Myers in their monumental work "Principles of Corporate Finance" (Brealey, Myers, 2004)). This method is applicable to capital cost correction when the structure of capital changes (namely, when the proportion between owners' and debt capital changes). According to this method, a three-step algorithm should be applied for the capital cost correction. At step one a debt load clearance of a weighted-average cost of capital is made or, in other words, alternative costs of debt capital are calculated as:

$$
r=r_{D} \frac{D}{V}+r_{E} \frac{E}{V}
$$

where $r$ - an alternative cost of capital fund raising into the project with similar risk level, $\mathrm{r}_{\mathrm{D}}$ - the cost of rising debt capital,

$\mathrm{r}_{\mathrm{E}}$ - the cost of rising stock capital,

D - the amount of debt capital,

E - the amount of stock capital, $\mathrm{V}$ - total capital $(\mathrm{V}=\mathrm{E}+\mathrm{D})$.

\footnotetext{
1 This means of calculation of the amount of new shares implies that the raised funds are invested into projects with such profitability and risk parameters that correspond with profitability of previously invested assets of the company and with the level of risk previously accepted by the company.
} 
At step two debt and stock capital costs are evaluated in a new capital structure (new debt to capital and debt to stock capital ratios) using the second Modigliani-Miller proposition to calculate the cost of stock capital:

$$
r_{E 2}=r+\left(r-r_{D 2}\right)\left(\frac{D}{E}\right)_{2},
$$

where $r_{E 2}$ - the adjusted cost of equity in a new capital structure, $r_{D 2}$ - the adjusted cost of debt in a new capital structure,

$(\mathrm{D} / \mathrm{E})_{2}$ - the new capital structure ratio.

At step three weighted average cost of capital is calculated, taking into account the new capital structure ratios and new cost of capital.

The above mentioned estimation method is appropriate, when the capital structure changes slightly once or twice within the affected period. However, if the company is planning a significant capital structure change, the weighted average cost of capital concept (the WACC formula) will not work. In such cases the Adjusted Present Value method (hereinafter referred to as "APV"), developed by Stewart Myers in 1974, should be used. (Myers, 1974). The APV model separately from the major project measures the total impact of such project effects as tax shield, change in the company's debt service capacity, as well as flotation costs. The APV model has proved to be successful when used for evaluation of parameters of transactions characterized by substantial change in capital structure (leveraged buyout (LBO) and management buyout (MBO)). At the same time it should be mentioned that as R. Brealey and S. Myers note, the APV method is applicable when the debt supported by a company or a project is linked to the balance value of the company (or the project) or when this debt is to be repaid under a fixed schedule. The authors do not claim the possibility to use this method unless these conditions are satisfied.

The method to evaluate the cost of capital upon the capital structure change proposed by K. Ferris and B. Pety (Ferris, Pettit, 2003) should also be mentioned. According to this valuation method calculation is made with the help of a discounted cash flow model, however, here a special technique is used to determine the discount rate for every forecast period starting from the last year and ending with the first forecast year. This method is logical and fairly universal, although it is fairly time-consuming in terms of execution of calculations. It should also be noted that this estimation method is only applicable in connection with minor changes in capital structure.

Extensive overview of balance between the cost of capital and various capital structure is introduced in the work of T. Copeland, T. Koller and J. Murrin (Copeland, Koller, Murrin, 2005). This work presents different ratios of weighted-average cost of capital to cost of unlevered capital, cost of levered equity capital to cost of unlevered equity capital, as well as levered "beta" and unlevered "beta" to debt "beta".

Extensive and probably the most detailed analysis of existing methods covering the estimated capital structure is introduced in the recently published work of P. Fernandez (Fernandez, 2015), who presents not only his own evaluation of Tax Shield (Fernandez, 2004), unlevered beta and unlevered company, but also the evaluation methods of Damodaran (Damodaran, 1994), Miles-Ezzel (Miles, Ezzel, 1980), (Miles, Ezzel, 1985 ), Myers (Myers, 1974) and HarrisPringle (Harris, Pringle, 1985). An interesting work of P. Fernandez (Fernandez, 2007) is also worth mentioning, where the APV and a WACC models are analyzed and compared. 
Finally, option-pricing models (Brealey, Myers, 2004), (Damodaran, 1994) should be mentioned, as those protected from changes in capital structure.

As mentioned earlier, the above approach refers to reporting of change in capital structure mainly when the cost of capital is estimated. In that context the author of this paper has set an aim to conduct a more detailed theoretical study of the way a company's capital structure changes influence the opportunities to estimate equity capital (but not the cost of capital). For this purpose the discounted cash flow method, shareholder value added model (SVA) and capitalization of added share revenue model were used. These models allow to reflect the effect of return on shareholders' equity connected with expectations of return from shareholders' invested funds raised due to additional issue of shares.

Another aspect that is worth noting is how the gain from the capital structure change will be distributed between the "old" and the new shareholders and how the expected company's stock value may change. Once again, we should note that application of SVA and capitalization of added share revenue models [by another name, capitalization of economic return to shareholders] allows to represent these questions in valuation calculations.

The information below reflects the author's attempt to present his own vision of the above estimation questions linked to the additional issue of shares and debt.

\section{METHOD}

\section{Influence of additional issue on the company's capital}

Let us analyze the way additional issue of shares influences the invested and stock capital and changes the price of a single share. To avoid additional complexity we shall restrict to cases without hybrid capital sources - privileged shares, convertible bonds, warrants, stock options, etc.

At first we shall examine the case, when an additional issue is made without attracting real cash (or any other assets) - by reducing the retained earnings with a simultaneous increase in the charter capital. As is well known charter capital may be increased by raising the nominal value of outstanding shares (without changing quantity thereof) and by increasing the quantity of shares without changing their nominal value (i.e. via additional issue). Since the capital of the company remains unchanged when additional issue is performed without attracting any new funds (assets), the total value of the outstanding shares also remains unchanged, however, the value of each single share should drop, because in cases where there is a constant dividend and an increased divisor the quotient inevitably drops:

$$
p_{\text {fin }}=p_{0} \times \frac{N_{0}}{N_{0}+N_{a d}},
$$

where $p_{\text {fin }}$ - the price of a single share after additional issue,

$p_{0}$ - the price of a single share prior to additional issue,

$N_{0}$ - the amount of outstanding shares prior to additional issue,

$N_{a d}$ - the amount of additionally issued shares.

Now let us analyze cases of capital change resulting from additional issue covered by the funds (assets) attracted from investors.

\section{Identification of the appraisal object}

\footnotetext{
2 We shall note that this way of additional issue is technically possible only with free distribution of additionally issued shares among the current shareholders in proportion to their participation interest and when there is no direct statutory prohibition for such way of placement of additionally issued shares.
} 
The first thing to be mentioned at the beginning of research of the declared topic is the problem of correct identification of the appraisal object in the situation, when the decision to make an additional issue has already been made and will be carried out in the near future. Usually when the value of shares is being appraised double identification of the appraisal object named "share package" is performed:

its part in the charter capital of the company and

- quantity of shares in units.

When additional issue is carried out the former shareholders can waive their right to acquire the issued shares, which will lead to a reduction of their initial participation interest in the capital of the company. Therefore, in such situations when economic calculations are performed it makes sense to refuse the traditional "double" identification of the appraisal object approach and concentrate on one of the parameters, provided that:

- if the appraisal object is the participation interest in the charter capital of the company, after the additional issue the only part of the cash flow to be taken into account during calculations is the one attributed to the original share;

- if the appraisal object is a share package nominated in quantity thereof (in units), after the additional issue the only part of cash flow to be taken into account is the one attributed to the evaluated number of shares (indicated in units) 4 .

\section{Influence of additional issue of shares on the invested capital}

When additional issue of shares takes place, changes in value of the invested capital $\left(\Delta V_{I C}\right)$ will depend on the volume of net raised capital $(M)^{5}$, expected profitability and risks of investment of raised funds:

$$
\Delta \mathrm{V}_{\text {IC }} \leq / \geq \mathrm{M} \text {, if } \mathrm{ROIC}_{\mathrm{n}} \leq / \geq \mathrm{ROIC}_{\mathrm{o}}, \mathrm{WACC}_{\mathrm{n}} \geq / \leq \mathrm{WACC}_{\mathrm{o}} \text {, }
$$

where « $\leq / \geq »$ means that correlation between mentioned amounts can be characterized as "less or equal" or "more or equal",

ROIC $_{n}$ - the expected return on invested capital gained as a result of additional issue of shares, $\mathrm{ROIC}_{\mathrm{o}}$ - the return on previously invested capital, WACC $_{n}$ - the weighted-average cost of capital after the additional issue of shares, WACC $_{o}$ - the weighted-average cost of capital prior to the additional issue of shares.

When paid by monetary assets (M) and upon assumption that return on invested capital gained as a result of additional issue of shares $\left(\mathrm{ROIC}_{n}\right)$ would be equal to return on previously invested capital $\left(\mathrm{ROIC}_{0}\right)$ and the cost of added capital $\left(\mathrm{WACC}_{\mathrm{n}}\right)$ would also be equal to the cost of previously raised capital $\left(\mathrm{WACC}_{\mathrm{o}}\right)$, the change of value of total invested capital (increase in value thereof - $\left(\Delta V_{I C}\right)$ ) would be equal to the total net raised capital. If the above assumptions are not observed, changes to value of invested capital conditioned by placement of additional issue of shares may differ from this amount.

\footnotetext{
3 This type of calculation should be used when the issuing company attracts additional funds from the current shareholders and the appraised participation interest does not change.

4 This type of calculation should be used when the issuing company attracts additional funds from outside investors who become the company's new shareholders.

${ }^{5}$ Here the net raised capital means the difference between the funds raised as a result of additional issue of shares and the cost of arranging the additional issue.
} 


\section{Influence of additional issue of shares on equity capital}

In case additional issue of shares takes place, changes in value of the equity capital $\left(\Delta \mathrm{V}_{\mathrm{E}}\right)$ will depend on the volume of raised capital $M$, as well as return and risks related to investment of raised funds:

$$
\Delta V_{\mathrm{E}} \leq / \geq \mathrm{M} \text {, if } \mathrm{ROE}_{\mathrm{n}} \leq / \geq \mathrm{ROE}_{\mathrm{o}}, \mathrm{r}_{\mathrm{n}} \geq / \leq \mathrm{r}_{\mathrm{o}},
$$

where « $\leq / \geq »$ means "less or equal" or "more or equal", $\mathrm{ROE}_{\mathrm{n}}$ - the expected return (for shareholders) on investment of raised funds (expected return on equity),

$\mathrm{ROE}_{\mathrm{o}}$ - the return on previously invested equity capital,

$\mathrm{r}_{\mathrm{n}}$ - the expenses on shareholders' capital after additional issue of shares,

$r_{0}$ - the expenses on shareholders' capital prior to additional issue of shares.

In the same manner, when paid by monetary assets $(\mathrm{M})$ and upon assumption that return on investment of equity capital raised via additional issue of shares ( $\mathrm{ROE}_{\mathrm{n}}$ ) would be equal to the return on previously invested equity capital $\left(\mathrm{ROE}_{0}\right)$ and that expenses on raising of additional equity capital $\left(r_{n}\right)$ would also be equal to expenses of previously raised equity capital $\left(r_{0}\right)$, change of value of total invested equity capital (increase in value thereof $-\left(\Delta \mathrm{V}_{\mathrm{E}}\right)$ ) would be equal to total net raised capital. If the above assumptions are not observed, changes to value of equity capital conditioned by placement of additional issue of shares may differ from this amount.

\section{Influence of additional issue of shares on distribution of profits between "old" and new shareholders \\ When performing additional issue of shares in the general case ${ }^{6}$ several situations are possible.}

Situation 1. The price of placement of additionally issued shares is lower than their current share (market) price. This is a very rare situation, but it is nevertheless possible if the following conditions or circumstances are present:

- There is low demand on these shares and high demand on raised funds;

- The company's management intentionally dilutes existing shareholding packages in favor of affiliated parties. In this situation while other parameters remain the same, old shareholders "concede" (lose) a part of value of their assets in favor of new shareholders (of course, if the whole new issue of shares is not placed with previous shareholders);

- In certain cases when there exists a well-grounded prognosis of super effective return on funds of strategic investors (new shareholders) invested as a result of additional issue of shares - in this situation "old" shareholders could offer investors a discount from the current market value of shares since in the case at hand "old" shareholders can raise the value of their assets (even considering the discount provided in relation to additionally issued shares);

- When immediately prior to effectuating the additional issue of shares the market value of the shares of this issuer $\left(\mathrm{V}_{\mathrm{m}}\right)$ is higher than their internal or intrinsic price $\left(V_{\text {internal }} / V_{\text {intrinsic }}\right)$ and this difference is large enough to "cover" the effect of concession of part of assess of the "old" shareholders7 (i.e. $\mathrm{V}_{\text {internal }}<\mathrm{P}_{\text {placement }}<\mathrm{V}_{\mathrm{m}}$ ) and it is known to a particular group of interested solvent investors ${ }^{8}$.

\footnotetext{
${ }^{6}$ Without considering statutory restrictions currently in effect.

${ }^{7}$ If such effect takes place.

${ }^{8}$ Essentially, this situation is a combination of the first and the third above mentioned conditions with the first one being dominant. In other words, it may mean an "overheating" of the market of these shares.
} 
Situation 2. Price of placement of additionally issued shares exceeds the current market value $\left(\mathrm{V}_{\mathrm{m}}<\mathrm{P}_{\text {placement}}\right)$.

This situation is possible if the following conditions or circumstances are present:

- High demand on shares being issued;

- Market expectations concerning development and functioning of the issuing company are mainly positive;

- When upon additional issue of shares the market value of shares $\left(\mathrm{V}_{\mathrm{m}}\right)$ is lower than their internal or intrinsic price $\left(\mathrm{V}_{\text {internal }} / \mathrm{V}_{\text {intrinsic }}\right)$ and this is known to a particular group of interested solvent investors.

In this situation, with all other parameters remaining unchanged, the "old" shareholders will be in a favorable position at the expense of new shareholders (only if all or part of the new issue of shares is placed with new shareholders). However, even in this case the old shareholders could lower the value of their assets (wealth) if expected net present value (NPV) of funds invested due to additional issue of shares appear to have a substantially negative value or such law positive value, that funds received over the market (by the old shareholders) from additional issue of shares would be lower than the change of monetary assets expected as a result of deduction of their share in the capital upon the issue of new shares ${ }^{9}$. The same situation will take place if at the moment of carrying out the additional issue of shares the market price of shares is considerably lower than their internal (or intrinsic) price, and the difference is so substantial that the bonus to the market price that appeared upon placement of the additional issue does not exceed the difference between internal and current market value of the equity capital (i.e. $\mathrm{V}_{\mathrm{m}}<\mathrm{P}_{\text {placement }}<\mathrm{V}_{\text {internal}}$ ).

Let us review in more detail the effect of distribution of profit derived from additional issue of shares between shareholders upon placement of new shares. The following designations should be introduced:

$\mathrm{p}_{0}$ - the market price of one share before placement of additionally issued shares,

$\mathrm{p}_{\mathrm{n}}$ - the price of placement of each additionally issued share,

$\Delta \mathrm{p}$ - the difference between the price of placement of one share as part of additional issue and the market value of one share immediately before the commencement of placement of the additional issue $\left(\Delta \mathrm{p}=\mathrm{p}_{\mathrm{n}}-\mathrm{p}_{0}\right)$,

$\mathrm{N}_{0}$ - the number of previously placed shares,

$\mathrm{N}_{\mathrm{ad}}$ - the number of shares additionally placed during the additional issue of shares,

$\mathrm{M}$ - the volume of monetary assets drawn by the issuing company as a result of placement of additionally issued shares, or monetary equivalent of non-monetary assets raised by the company as a result of additional issue of shares,

$\mathrm{MC}_{\mathrm{A}}$ - the market capitalization of the issuing company after placement of the additional issue of shares,

$\mathrm{MC}_{\text {est }}$ - the estimated (calculated) value of capitalization of the issuing company after placement of the additional issue of shares,

$p_{\text {est }}$ - the estimated value of price per share of the issuing company at the moment of termination of additional issue.

Taking into consideration the above designations, let us perform a theoretical and practical evaluation of "distributing" effects conditioned upon the additional issue.

\footnotetext{
${ }^{9}$ This change by itself will be conditioned upon the reduction of the former shareholders' share in the capital of the company (unless they purchase all the additionally issued shares) and probably by a change in total ROIC.
} 
Theoretical effect: After new shares are placed with the price of $p_{n}$ the price of such shares on the secondary market remained unknown. In this situation it is difficult to make a conclusion as to the volume of market capitalization of the whole company - in this regard only an evaluative estimation could be made, based on information on the former (before the additional issue) volume of market capitalization of the issuing company and volume of raised funds as a result of placement of new shares:

$$
\mathrm{MC}_{\mathrm{est}}=\mathrm{p}_{0} \mathrm{~N}_{0}+\mathrm{M}=\mathrm{p}_{0} \mathrm{~N}_{0}+\mathrm{p}_{\mathrm{n}} \mathrm{N}_{\mathrm{ad}}
$$

In this situation one could try to evaluate the estimated value of price of one share ( $\mathrm{p}_{\text {est }}$ ) of the issuing company at the moment of termination of additional issue:

$$
p_{\text {est }}=\frac{p_{0} N_{0}+p_{n} N_{a d}}{N_{0}+N_{a d}}=p_{0}+\Delta p \cdot \frac{N_{a d}}{N_{0}+N_{a d}} .
$$

According to this evaluative calculation the "old" shareholders will change (raise at $\Delta p>0$ ) the level of their wealth for $\Delta \mathrm{p} \mathrm{N}_{\mathrm{ad}} /\left(\mathrm{N}_{0}+\mathrm{N}_{\mathrm{ad}}\right)$, and the "new" shareholders will become "poorer" for $\left(1-\Delta \mathrm{p} \mathrm{N} \mathrm{N}_{\mathrm{ad}} /\left(\mathrm{N}_{0}+\mathrm{N}_{\mathrm{ad}}\right)\right)$ - all calculations are done in relation to each single share owned by them.

Real effect: In reality after placement of additionally issued shares the price of shares on the market will settle at some new level $\left(\mathrm{p}_{\text {fin }}\right)$. Thus, the effect of placement of additionally issued shares when calculated per one share shall constitute:

- For former shareholders - - $\left(\mathrm{p}_{\mathrm{fin}}-\mathrm{p}_{0}\right)$;

- For new shareholders - - $\left(\mathrm{p}_{\mathrm{fin}}-\mathrm{p}_{\mathrm{n}}\right)$;

Let us analyze two particular cases as parts of the real effect described above.

Particular case 1: after placement of new shares at the $p_{n}$ price, the price of these shares on the secondary market $\left(\mathrm{p}_{\mathrm{fin}}\right)$ remained the same (unchanged): $\mathrm{p}_{\mathrm{fin}}=\mathrm{p}_{0}$.

In this situation the market capitalization of the issuing company after placement of all the additionally issued shares shall constitute:

$$
\mathrm{MC}_{\mathrm{A}}=\mathrm{p}_{0} \mathrm{~N}_{0}+\mathrm{p}_{0} \mathrm{~N}_{\mathrm{ad}}=\mathrm{p}_{0}\left(\mathrm{~N}_{0}+\mathrm{N}_{\mathrm{ad}}\right)
$$

In this case the "old" shareholders will not change the level of their wealth and the "new" shareholders will become "poorer" for $\Delta \mathrm{p}$ (with $\mathrm{p}_{\mathrm{n}}>\mathrm{p}_{0}$ ) calculated as per each share acquired by them for the price of placement $\left(\mathrm{p}_{\mathrm{n}}\right)$ thereof.

Particular case 2: after placement of new shares at the price of $\mathrm{p}_{\mathrm{n}}$, the price of these shares on the secondary market has settled at a new level: $\mathrm{p}_{\mathrm{fin}}=\mathrm{p}_{0}+\Delta \mathrm{p}=\mathrm{p}_{\mathrm{n}}$.

In this situation the market capitalization of the issuing company after placement of all additionally issued shares shall constitute:

$$
M C_{A}=p_{n} N_{0}+p_{n} N_{a d}=p_{n}\left(N_{0}+N_{a d}\right)
$$

In this case those who derive a whole benefit from the placement of the additional issue are the "old" shareholders: they will become wealthier at $\Delta \mathrm{p}$ calculated as per each of their shares. 
Let us note that with substantial volume of additional issue (comparable to previously raised share capital or exceeding it) the process of additional issue could be compared to the accession of one company to another company, when the shares of the absorbed (acquired) company are converted into the shares of the absorbing company (being the consolidation center) with a certain exchange coefficient (conversion). However, unlike the process of accession, in the additional issue process the funds of the new shareholders are used as payment for the transaction instead of the shares of the absorbed company. Essentially these funds are converted into shares of their new company.

Situation 3. The price of placement of additionally issued shares is equal to the current market value.

This situation is possible if the following conditions or circumstances are present:

- There is a balance of demand and supply on the secondary market of these shares;

- There is a considerably small volume of placed shares and the secondary market for them is dynamic.

In this situation a lot depends on the expected return of the invested funds received as a result of the additional issue and (for the old shareholders) on how justly the market evaluated the issuer's shares as of the moment of the additional issue.

Let us note that in a situation with previously achieved market balance with small volume of additional issue and absence of information on expected profit from additionally issued shares, the quantity of shares planned for issue can be calculated in the following manner:

$$
N_{a d}=\frac{M}{p_{0}} .
$$

Let us also note that the possible effect of maximization of profits expected by the old shareholders from gaining funds could consist of allocation of these funds to payment of dividends (to themselves). If such is the case, the old shareholders could enlarge the value of ownership of their shares (of course, only if reduction of the present value of the expected cash flow appears to be lower than the current dividends received by them). This is possible if in the years to come no receipt of profit and/or payment of dividends is contemplated, or if expected dividends are too low ${ }^{10}$.

\section{Evaluation of the new shareholders' share in the capital of the company}

Let us determine the intrinsic share in the capital of the company for the new shareholders that invest additional assets into the company ${ }^{11}$. In order to avoid complicating the description, let us hereinafter presume that the "old" shareholders are a "solid" mass of shareholders that share a single position as regards the necessity to perform additional issue of shares (if this is not the case, we will presume that the parties that initiated the additional issue (majority shareholders) performed all the necessary payments in favor of minority shareholders, who voted against additional issue of shares, before the issue was made).

\footnotetext{
${ }^{10}$ Please also note that it is only possible if such scheme is technically feasible (as regards terms and procedures of payment of dividends established in the company).

${ }^{11}$ In other words, let us determine the fair size of the package of shares that is to be transferred to new shareholders during investment into the company (via purchase of shares thereof) of additional assets.
} 
Evaluation of the new shareholders' share of participation is usually calculated as follows:

$$
S h_{n}=\frac{N_{n s}}{N_{0}+N_{a d}}=\frac{N_{n s}}{N_{0}+N_{n s}+N_{f s}}=\frac{M}{V_{E 0}+M+M_{f s}}
$$

where $S h_{n}$ is the share of the new shareholders in the capital of the company,

$N_{0}$ - the number of previously issued shares (before additional issue),

$N_{n s}$ - the number of additionally issued shares purchased by new shareholders,

$N_{f s}$ - the number of additionally issued shares purchased by former ("old") shareholders (or received by them via privileged subscription),

$N_{a d}$ - the total number of additionally issued shares equal to $\left(N_{n s}+N_{f s}\right)^{12}$,

$M$ - the sum of funds (assets) of the new shareholders raised as a result of additional issue of shares ${ }^{13}$,

$M_{f s}$ - the sum of funds (assets) of the "old" (former) shareholders raised as a result of additional issue of shares,

$V_{E O}$ - the market value of equity capital of the company before the funds received from the additional issue are invested into it.

Let us now consider more fully assess methods the shareholders shares in the capital of the company.

\section{Evaluation of shares in the capital of the company for the cases of redemption of shares additionally issued by the new shareholders}

The use of the expression (11) for determining the share of the equity of the company is suitable in all cases where the value of funds introduced new shareholders coincides with the value of the company's growth in market value. This increase is due to the involvement of new capital by placing additional shares issued. In most cases, such a coincidence is observed in payment for the new shares by cash. However, the new shareholders may pay the capital increase not only cash, but also other assets, such as movable or immovable property, lease rights or other intangible assets. In most cases, the value of the contribution to the authorized capital can be determined by an adequate assessment of the market value of the property contributed to the authorized capital. However, in some cases the use of the property contributed to the authorized capital, in the company issuing the shares may be more favorable than the market average, that is, there may be a special (synergistic, investment) value of the property to the company, differs from the market value. In such cases, to evaluate the interest of new shareholders (Shn) instead of the expression (11) should apply different methods of calculation:

$$
S h_{n}=\frac{\Delta V}{V_{0}+\Delta V}
$$

or

12 If all the shares under the additional issue are acquired by the new shareholders, the following equivalence will be preserved: $N_{n s}=N_{a d}$.

${ }^{13}$ In the general case $M$ can be considered as contribution of the new shareholders into the issuing company's business. For example, it can be a net cash flow growth of the issuer during a certain period as a result of positive participation of the abovementioned parties in the business of the issuer. 


$$
S h_{n}=\frac{M+k \cdot \Delta}{V_{0}+M+\Delta},
$$

where $\mathrm{V}_{0}$-the market value of the company's capital to implement the additional issue, $\Delta \mathrm{V}$-increase in the market value of the company's capital as a result of the placement of new shares and receive payment in assets, the market value of which is equal to $M$,

$\Delta$-added value (cost) of the property contributed as payment for the shares to the issuing company (the total cost is equal to $M+\Delta$ ),

$\mathrm{k}$ - part of the added value contributed as payment for the property, referred to the proportion of new shareholders $(0 \leq \mathrm{k} \leq 1)$; the fair value of this parameter can be calculated using the expression:

$$
k=\frac{M+\Delta}{V_{0}+M+\Delta},
$$

but in general it is determined in the process of negotiating new and old shareholders.

Evaluation of equity in the company to repurchase an additional cases of issued shares of old shareholders in an amount in proportion to their participation, prevailing prior to the implementation of additional issue.

In this case, the proportion of old shareholders remain unchanged.

Evaluation of equity in the company to repurchase an additional cases of issued shares of old shareholders in the amount disproportionate shares of their participation, prevailing prior to the implementation of additional issue.

In cases where the entire additional share issue of buying back the former shareholders in the amount of disproportionate previously held their shares, estimate the share of participation of each of the shareholders it is advisable to carry out the following:

$$
S h_{i}^{A F T E R}=\frac{S h_{i}^{B E F O R E} \cdot V_{0}+S h_{i}^{S P O} \cdot M}{V_{0}+M}
$$

where $\mathrm{Sh}_{\mathrm{i}} \mathrm{AFTER}$ - share of $\mathrm{i}$-th shareholder in the capital of the company after the acquisition of additional shares in the total emission of $\mathrm{M}$,

$\mathrm{Sh}_{\mathrm{i}} \mathrm{BEFORE}^{-}$the share of the $\mathrm{i}$-th shareholder in the company before placing additional shares issued,

$\mathrm{Sh}_{\mathrm{i}} \mathrm{SPO}$ - share acquisition of the i-th shareholder in the total volume of newly placed shares, $\mathrm{V}_{0}$ - the market value of the company's capital to implement the additional issue, $\mathrm{M}$ - the amount raised as a result of the additional issue of shareholders' funds.

Evaluation of shares in the capital of the company for the cases of redemption of shares additionally issued by the new and old shareholders All of the old shareholders redeem shares additionally issued shares in proportion to the prevailing earlier, and the rest of the shares buy back the new shareholders In cases where all the old shareholders buy back part of the additional shares issued in proportion to available shares, and the remainder of the shares issued additionally buys a new 
shareholder, the evaluation of interests in the company it is advisable to carry out the following:

$$
\begin{aligned}
& S h_{\text {oldi }}^{A F T E R}=S h_{\text {oldi }}^{\text {BEFORE }} \cdot \text { TotalSh }_{\text {old }}^{\text {AFTER }}, \\
& {\text { Total } S h_{\text {old }}^{A F T E R ~}}_{\text {old }}=1-S h_{n}, \\
& S h_{n}=\frac{M_{\text {new }}}{V_{0}+M}=\frac{M_{\text {new }}}{V_{0}+M_{\text {old }}+M_{\text {new }}},
\end{aligned}
$$

where $S h_{\text {oldi }}^{A F T E R}$ - the share of the i-th former ("old") a shareholder in the company after the placement of additional shares,

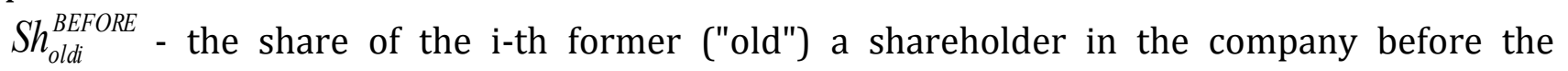
placement of additional shares,

TotalSh old $_{\text {ofTR }}$ - the total share of the previous ("old") of shareholders in the company's capital after the placement of additional shares,

$S h_{n}$ - the proportion of new shareholders in the company's capital after the placement of additional shares,

$M_{n e w}$ - the amount of money spent by the new shareholders for the acquisition of additional shares issued,

$M_{\text {old }}$ - the amount of money spent by the former ("old") shareholders to acquire additionally issued shares,

$M$ - сумма денег, привлеченных в процессе размещения дополнительно эмитированных акций,

$V_{0}$ - the market value of the company's capital prior to the additional issue of shares.

The old shareholders buy back part of the additional shares issued disproportionately prevailing prior to their shares, the rest of the shares buy back the new shareholders

In cases where the old shareholders buy back part of the additional shares issued disproportionately prevailing prior to their shares, and the remainder of the shares buy back the new shareholders, evaluate interest of $i$-th shareholder in the company is advantageously carried out as follows:

$$
S h_{i}^{A F T E R}=\frac{S h_{i}^{B E F O R E} \cdot V_{0}+S h_{i}^{S P O} \cdot M}{V_{0}+M} \times \text { TotalSh }_{\text {old }}^{A F T E R},
$$

where all the designations are consistent with previously made.

Let us note that if during the negotiation process the shareholders agreed with the investors on distribution of shares at the cost of issue of new shares (i.e. they determined the $S h_{n}$ parameter), the number of shares issued in favor of the new shareholders-investors will constitute:

$$
N_{n s}=\frac{S h_{n}}{1-S h_{n}} \times N_{o} .
$$




\section{Evaluation of price of shares when information on the forthcoming additional issue is available: application of discounted cash flow method}

Let us analyze the procedure of evaluation of the current share package value in a situation when it has become known that in a certain moment of the forecast period (distanced from the evaluation moment for the period the duration of which cannot be disregarded) the managers of the company plan to carry out an additional issue of shares. Respective formal requirements of applicable legislation will not be taken into consideration for the purposes of this analysis. When information that in the foreseeable future the company plans to carry out additional issue becomes available and the volume of such issue is comparatively large (yet substantially lower than the volume of the capital previously placed by the shareholders), during the informal evaluation the factor of additional issue can be accounted as follows.

1. At first it is necessary to make an assumption regarding the options of using the funds raised as a result of the additional issue. For example, it is possible to assume that the funds raised from the additional issue will be invested into the main business of the company and not immediately paid as dividends to its former shareholders.

2. Afterwards it is necessary to make an assumption related to the structure of shareholders who will purchase the additionally issued shares. For example, it is possible to assume that the owner of the evaluated share package will or will not purchase additional shares from the placed additional issue.

3. If in the forecast period only one additional issue is contemplated, it is necessary to adjust the expenses related to raising of equity capital (the discount rate) using the following algorithm:

Firstly, it is necessary to determine how the alternative price of the borrowed capital will change upon alteration of indebtedness $\left(r_{D A}\right)$. Usually when indebtedness decreases the alternative price of the borrowed capital is reduced as well.

\section{After that, according to the second Modigliani-Miller proposition the evaluation of the adjusted expenses for raising of the company owners' equity is carried out with a new debt ratio:}

$$
r_{a d j}=R+\left(R-r_{D A}\right) \frac{D}{E+M}
$$

where $R$ is alternative costs of raising the capital of the company (determined exclusively by parameters of the risk level inherent to the business, not considering the debt load);

$r_{D A}$ - the costs of raising (alternative costs) of the borrowed capital with adjustment of debt to own capital ratio up to level $\mathrm{D} /(\mathrm{E}+\mathrm{M})$;

$r_{a d j}$ - the adjusted costs of raising (alternative costs) of equity capital with the debt to own capital ratio being at level $\mathrm{D} /(\mathrm{E}+\mathrm{M})$;

$D$ - the market value of the borrowed capital after the additional issue (i.e. in the general case, with possible changes not only of expenses related to raising of the debt financing, but also of the total amount of debt, if it changes);

$E$ - the market value of the equity capital before the additional issue;

$M$ - the volume of funds raised as a result of additional issue. 
4. Price of the evaluated share package owned by the former shareholders ${ }^{14}$ is determined as the present value of the cash flow in relation to each of them for the period from the date of evaluation to the moment of additional issue and the cash flows related to the share of former shareholders for the period following the additional issue of shares:

$$
V_{f s}=s h_{0}\left(\sum_{i=1}^{k} \frac{F C F E_{i}}{(1+r)^{i}}-\frac{E E}{\left(1+r_{f}\right)^{k}}+\frac{M}{\left(1+r_{f}\right)^{k}}\right)+s h_{A}\left(\sum_{i=k+1}^{n} \frac{F C F E_{i}}{\left(1+r_{a d j}\right)^{i}}+\frac{T V}{\left(1+r_{a d j}\right)^{n}}\right)
$$

With $V_{f s}$ - being the price of the evaluated package of shares owned by former ("old") shareholders before the additional issue,

$s h_{0}$ - the part of the equity capital held by the owners of the evaluated package of shares before the additional issue,

$k$ - the moment (period) of placement of additionally issued shares,

$n$ - the number of the final year of the forecast period,

$s h_{A}$ - the part of the equity capital held by the owners of the evaluated package of shares after the additional issue of shares $\left(s h_{A}<s h_{0}\right)$,

$F C F E_{i}$ - the cash flows of the shareholders in the i period 15 ,

$r$ - the discount rate applicable to cash flows of shareholders prior to the additional issue of shares (expenses related to raising of equity capital before the additional issue),

$E E$ - the issue-related costs connected with expenses for issue and placement of new shares,

$r_{f}$ - the risk free discount rate,

$r_{\text {adj }}$ - the discount rate applicable to cash flows of shareholders after the additional issue,

$T V$ - the terminal value of the equity capital formed by income flows of the post-forecast period.

If for the purposes of evaluation of the price of the share package the emphasis is made not on the quantity of shares, but on the share of participation in the capital, instead of the previous formula a different calculation model should be used ${ }^{16}$ :

$$
V_{f s}=s h_{0}\left[\sum_{i=1}^{k} \frac{F C F E_{i}}{(1+r)^{i}}-\frac{E E}{\left(1+r_{f}\right)^{k}}-\frac{M}{\left(1+r_{f}\right)^{k}}+\sum_{i=k+1}^{n} \frac{F C F E_{i}}{\left(1+r_{a d j}\right)^{i}}+\frac{T V}{\left(1+r_{a d j}\right)^{n}}\right],
$$

where all designations correspond to the previously stated ones.

In order to calculate the present value of cash flows for the period after the additional issue one should construct an adjusted forecast of cash flow of shareholders from the moment of commencement of the additional issue to the moment of termination of the forecast period. If the "old" shareholders do not plan to buy additionally placed shares or if the object of evaluation is a particular quantity of shares placed earlier, during the period of additional issue

\footnotetext{
${ }^{14}$ It is necessary to make an important elaboration at this point: the object of evaluation within the frame of the valuation method bellow is a package of shares categorized by their quantity (units, "pieces"), and not their participation interest in the charter capital. Isolation of this evaluation object is reasonable in cases where owners of the share package subject to evaluation do not plan to purchase additionally issued shares.

15 Let us note that according to the presented equation (22) and equation (23) that follows it, the expenses for the issue are not taken into consideration in share flows in the k period, since in these equations they are separately represented by the "EE" entry.

16 This calculation model should be applied when owners of the evaluated package of shares plan to purchase additionally issued shares in the amount proportional to their share of participation in the charter capital of the company that has formed prior to the additional issue.
} 
it is possible to reasonably expect enhanced cash flows for the amount of cash raised as a result of placement of these shares, but in return in the following periods it will be necessary to consider the reduction of the fraction of income related to their (these) shares. Adjustments that reflect the fact of additional issue should also account for possible changes in total flows of the company conditioned by change in return on new investments raised in the process of the additional issue. On the contrary, if the "old" shareholders purchase all additionally issued shares, their investments will initially trigger an outflow of cash diverted to purchase these shares, and in return the whole return on additional investments will remain with them in the following years.

Both of the above valuation calculations in accordance with equations (22) and (23) can be adapted for purposes of price evaluation of a single share, taking into consideration the planned additional issue of shares. For this purposes it should be borne in mind that the price of the evaluated share package $\left(V_{\mathrm{fs}}\right)$ shall equal to the product of the market value of one share $\left(\mathrm{v}_{1}\right)$ and the total quantity of shares in the evaluated share package $\left(\mathrm{V}_{\mathrm{fs}}=\mathrm{v}_{1} \times \mathrm{N}_{0}\right)$, while the amount of funds raised as a result of additional issue of shares (M) shall equal to the product of the market value of one share and the total number of additionally issued shares $\left(\mathrm{M}=\mathrm{v}_{1} \times \mathrm{N}_{\mathrm{ad}}\right)$. The substitution of the stated values of $V_{f s}$ and $M$ in (22) will result in the following equation for the calculation of the expected price of one share using the discounted cash flow model that takes into account the expected effects of the planned additional issue:

$$
v_{1}=\frac{s h_{0} \cdot\left(\sum_{i=1}^{k} \frac{F C F E_{i}}{(1+r)^{i}}-\frac{E E}{\left(1+r_{f}\right)^{k}}\right)+s h_{A} \cdot\left(\sum_{i=k+1}^{n} \frac{F C F E_{i}}{\left(1+r_{a d j}\right)^{i}}+\frac{T V}{\left(1+r_{a d j}\right)^{n}}\right)}{N_{0}-\frac{N_{a d} \cdot s h_{0}}{\left(1+r_{f}\right)^{k}}},
$$

where other designations correspond to the previously stated ones.

It should be noted that equation (24), as well as equation (22), should be used when the owner of the evaluated share or evaluated share package does not plan to purchase additionally issued shares.

A similar substitution of the above stated values of $V_{\mathrm{fs}}$ and $\mathrm{M}$ into (23) will result in the following equation for the calculation of the expected price of one share using the discounted cash flow model that takes into account the expected effects of the planned additional issue:

$$
v_{1}=\frac{s h_{0} \cdot\left[\sum_{i=1}^{k} \frac{F C F E_{i}}{(1+r)^{i}}-\frac{E E}{\left(1+r_{f}\right)^{k}}+\sum_{i=k+1}^{n} \frac{F C F E_{i}}{\left(1+r_{a d j}\right)^{i}}+\frac{T V}{\left(1+r_{a d j}\right)^{n}}\right]}{N_{0}-\frac{N_{a d} \cdot s h_{0}}{\left(1+r_{f}\right)^{k}}},
$$

where all designations correspond to the previously stated ones.

It should be pointed out that equation (25), as well as equation (23), should be used when the owner of the evaluated share or evaluated share package plans to purchase additionally issued shares in the amount proportional to his share of participation in the charter capital of the company that has been formed prior to the additional issue.

It should be noted that receipt of information on the additional issue can by itself trigger certain changes in the price of shares. If we assume that return on monetary funds raised in 
connection with the additional issue appears to be equal to return on previously invested capital of the company, and that the volume of contemplated issue is comparatively small, such signal effect ${ }^{17}$ can usually be ignored.

In cases when a company plans considerable recapitalization (for example, the contemplated volume of additional issue is comparable to or exceeds the previously placed capital of shareholders, or full settlement of existing debt is contemplated), the model based on discounting of cash flows of the company under weighted-average cost of capital method ceases to work. In such cases one should use the adjusted present value method (APV Adjusted Present Value) developed by Stewart C. Myers (Myers, 1974; Brealey, Myers, 2004).

\section{Evaluation of shares' price upon additional issue: application of Shareholders' Value Added model}

Let us analyze the case in which the equity capital of the company is comprised only from ordinary shares and additional issue of ordinary shares is contemplated. Let us assume that the cost of the equity capital of the issuer before the additional issue is $V_{E 0}=p_{0} N_{0}$, where $p_{0}$ is the market value of a single share, and $N_{o}$ is the total quantity of shares. Let us also assume that the shareholders received an offer from an investor(s) related to business development. Investor is ready to invest an amount $M$. Size of the investor's share could be determined using formula (11). As it was indicated earlier, depending on the anticipated economic effect of the additional issue and the decision on the quantity of newly issued shares, the market price of shares of the company after the additional issue can change $\left(p_{\text {fin }} \neq p_{o}\right)$ or remain unchanged $\left(p_{\text {fin }}=p_{o}\right)$. With that in mind if there are grounds to expect considerable economic effect from monetary funds raised as a result of the additional issue, the market value of equity after the additional issue can be calculated using the Shareholders' Value Added model:

$$
V_{E A}=V_{E O}+M \cdot\left[1+\sum_{i=1}^{m} \frac{\left(R O E_{i}-r_{e}\right)}{\left(1+r_{e}\right)^{i}}\right],
$$

where $V_{E A}$ - is the market value of equity after the additional issue,

$V_{E O}$ - is the market value of equity before the additional issue,

$R O E_{i}$ - the return on equity in the i period,

$R_{e}$ - the alternative costs for raising share capital,

$\mathrm{m}$ - the period in which ROEi $\geq$ re condition is expected to be completed.

Now let us assume that the evaluator has grounds to believe that in future the correlation between return on the raised equity capital and its alternative value will stay on the same level (equal to $R O E_{n} / r_{e n}$ ) for a long time and that the volume of the additional issue is not particularly large. With these conditions observed, it becomes possible to apply Shareholders' Value Added Capitalization model (also known as Shareholders' Economic Profits Capitalization model). In this case equation (18) could be extended and indicated as follows:

\footnotetext{
${ }^{17}$ Signal effect is the effect of adjustment of the stock exchange share prices upon receiving information on the forthcoming additional issue. Usually as a result of this effect the price of shares of the issuer that prepares the additional issue falls (if the shares are listed on the market), since the typical potential buyer of shares of this company thinks in approximately the following manner: "if main shareholders and top managers of the company want to do this it means that they, while possessing all internal information on the status of the company, decided that the current market value is higher than the internal price of the company, and thus it is reasonable for them to use the occasion to decrease the share of their participation in the company. If this is the case it is unadvisable for me to purchase these shares for the current market price. And in case I decide to purchase them, I will only do so with a discount to their market price".
} 


$$
V_{E A}=V_{E 0}+M \frac{R O E_{n}}{r_{e n}}=p_{0} N_{0}+M \frac{R O E_{n}}{r_{e n}}=\left(E_{0}+M\right) \times<\frac{R O E}{r_{e}}>\text {, }
$$

where $E_{0}$ - is the capital actually invested by the old shareholders. Connection of this index with expected return on equity that was placed earlier $\left(R O E_{0}\right)$, investment costs $\left(r_{e 0}\right)$, market value of a single share $\left(p_{0}\right)$ and quantity of previously placed shares $\left(N_{0}\right)$ is as follows:

$$
E_{0}=\frac{p_{0} N_{0} r_{e 0}}{R O E_{0}}
$$

$<\mathrm{ROE} / \mathrm{r}_{\mathrm{e}}>$ in (27) signifies the weighted average (as regards the volume of equity of the old and the new shareholders) return on equity to the cost of capital ratio:

$$
\left\langle\frac{R O E}{r_{e}}\right\rangle=\frac{E_{0}}{E_{0}+M} \times \frac{R O E_{0}}{r_{e 0}}+\frac{M}{E_{0}+M} \times \frac{R O E_{n}}{r_{e n}}
$$

Taking into consideration equations (26) and (27) let us analyze the conditions in which the price of shares after the additional issue will remain the same or change.

\section{Conditions of change and immutability value per share in case of additional issue}

Let us return once again to equations (26) and (27) and write them down in a somewhat amended manner. For equation (26) we have:

$$
\begin{aligned}
& V_{E A}=p_{0} N_{0}+M \cdot\left(1+\sum_{i=1}^{m} \frac{\left(R O E_{i}-r_{e}\right)}{\left(1+r_{e}\right)^{i}}\right)=p_{f i n}\left(N_{0}+N_{a d}\right)= \\
& =\left(p_{0}+\Delta p\right)\left(N_{0}+N_{a d}\right),
\end{aligned}
$$

With $\Delta p$ being the volume of change in price of one share conditioned by the additional issue, $p_{\text {fin }}$ - the market price of one share after placement of additionally issued shares, from which follows:

$$
p_{f i n}=\frac{p_{0} N_{0}+M\left(1+\sum_{i=1}^{m} \frac{\left(R O E_{i}-r_{e}\right)}{\left(1+r_{e}\right)^{i}}\right)}{N_{o}+N_{a d}}
$$

and

$$
\Delta p=\frac{M\left(1+\sum_{i=1}^{m} \frac{\left(R O E_{i}-r_{e}\right)}{\left(1+r_{e}\right)^{i}}\right)-p_{o} N_{a d}}{N_{0}+N_{a d}} .
$$

For equation (27) we have:

$$
V_{E A}=p_{0} N_{0}+M \frac{R O E_{n}}{r_{e n}}=p_{f i n}\left(N_{0}+N_{a d}\right)=\left(p_{0}+\Delta p\right)\left(N_{0}+N_{a d}\right),
$$

With $\Delta p$ being the volume of change in price of one share conditioned by additional issue, $p_{f i n}$ - the market price of one share after placement of additionally issued shares, from which follows: 
and

$$
p_{\text {fin }}=\frac{p_{0} N_{0}+M \frac{R O E_{n}}{r_{e n}}}{N_{o}+N_{a d}},
$$

$$
\Delta p=\frac{M \frac{R O E_{n}}{r_{e n}}-p_{o} N_{a d}}{N_{0}+N_{a d}} .
$$

It can be derived from equations (32) and (35) that in order for the price of one share after the additional issue to remain the same the number of issued shares $\left(N_{a d}\right)$ should constitute accordingly:

$$
N_{a d}=\frac{M\left(1+\sum_{i=1}^{m} \frac{\left(R O E_{i}-r_{e}\right)}{\left(1+r_{e}\right)^{i}}\right)}{p_{0}},
$$

and

$$
N_{a d}=\frac{M \frac{R O E_{n}}{r_{e n}}}{p_{0}} .
$$

If the above conditions are not observed, the price of one share should change when the additional issue is executed.

\section{Determining the quantity of issued shares}

Earlier we determined the means for calculation of number of placed shares with known number of placed shares and share of participation in the capital of new shareholdersinvestors (see equation (20)). Let us determine the number of issued shares with other parameters being known. To receive the necessary calculation formulae let us use equations (31) and (34) and draw from there in an apparent manner the necessary parameter $\left(\mathrm{N}_{\mathrm{ad}}\right)$ :

When Shareholders' Value Added model is applied, the number of shares necessary for the additional issue will be determined using the following equation (31):

$$
N_{a d}=\frac{\left(p_{0}-p_{f i n}\right) N_{0}+M\left(1+\sum_{i=1}^{m} \frac{\left(R O E_{i}-r_{e}\right)}{\left(1+r_{e}\right)^{i}}\right)}{p_{f i n}} .
$$

When Shareholders' Economic Profits Capitalization model is applied, the number of shares necessary for additional issue will be determined using the following equation (34):

$$
N_{a d}=\frac{\left(p_{0}-p_{f i n}\right) N_{0}+M \frac{R O E_{n}}{r_{e n}}}{p_{f i n}} .
$$

\section{Example}

For the purposes of this example the share capital of the company prior to the additional issue consisted of $N_{o}=100$ ordinary shares. The market price of one share $\left(p_{o}\right)$ constituted 1.5 
a.v.18.Investors are ready to invest $M=50$ a.v. into a new business line of the company. The expected return on this invested capital and capital expenses constitute: $R O E_{n}=30 \%, r_{e n}=15 \%$.

It is necessary to determine the equity capital value of the expanded (after the additional issue) company $\left(V_{E A}\right)$, the new shareholders' participation interest in its charter capital $\left(\mathrm{Sh}_{\mathrm{n}}\right)$, the number of issued shares $\left(N_{a d}\right)$ and the price of one share after the additional issue $\left(p_{f i n}\right)$.

\section{Solution}

Let us presume availability of all grounds for application of the Shareholders' Value Added Capitalization model. In this case in accordance with (33) the price of equity capital of the expanded company shall constitute:

$$
V_{E A}=p_{o} N_{o}+M \frac{R O E_{n}}{r_{e n}}=1.5 \times 100+50 \times \frac{0.3}{0.15}=250 \text { a.v. }
$$

In order to determine the share of the new shareholders it is necessary to know the quantity of shares which they will be offered to purchase. Of course, if the parties somehow agreed about this from the start (i.e. determined it empirically), the matter of quantity of shares issued in favor of the new shareholders would be easily determined using the formula (20).

For example, if parties agreed upon the volume of share of the new shareholders using formula (11): $\mathrm{Sh}_{\mathrm{n}}=50 /(1.5 \times 100+50)=0.25$, then, as it follows from $(20)$, it will be necessary to issue $\mathrm{N}_{\mathrm{ad}}=0.25 /(1-0.25) \times 100=33$ shares in favor of the new shareholders. In this case the price of one share shall constitute $p_{f i n}=V_{E A} /\left(N_{o}+N_{a d}\right)=250 /(100+33)=1.88$ a.v.

Let us note that if there were no grounds to expect the return on equity capital raised via the additional issue (according to the condition of the example - 0.3) to exceed more than twice the cost of capital (according to the condition of the example - 0.15), the market price of the equity capital could be evaluated differently: $150+50=200$ a.v., and the price of one share $200 /(100+33)=1.5$ a.v., meaning that in this case the price of one share would remain unchanged 19 .

Let us also note that while planning additional issue parameters the shareholders can simultaneously consider resolution of other matters (for example, raise or drop the price of one share). In order to do this it is necessary to research several possible options. Algorithms suggested in this work allow to consider at least two such options.

1. Let us assume that the shareholders wish the market price of a single share to remain practically unchanged after the additional issue. In this case taking into consideration the above conditions the quantity of shares necessary for the additional issue should be determined according to (37):

$$
N_{a d}=\frac{M \frac{R O E_{n}}{r_{e n}}}{p_{0}}=\frac{50 \times \frac{0.3}{0.15}}{1.5}=67 \text { units. }
$$

\footnotetext{
18 a.v. - «abstract value».
}

19 In this connection the simplest recommendation for the participants of the market that do not possess information on the expected return on investment of funds raised via the additional issue of shares is to purchase shares at their current market price or at a lower price. 
In this case the price of purchase of additionally issued shares by new shareholders should constitute 50 (a.v.)/ $67=0.75$ a.v.

In this scenario the price of one share after the additional issue shall constitute:

$p_{\text {fin }}=V_{E A} /\left(N_{o}+N_{a d}\right)=250 /(100+67)=1.5$ a.v.

(taking into consideration the measure of inaccuracy of the $N_{n}$ definition),

i.e. the price will remain the same, as the shareholders wanted.

Now, when we know the quantity of shares received by the old and the new shareholders, let us determine their share and value.

According to (11) the share of the new shareholders shall constitute:

$$
S h_{n}=\frac{N_{n s}}{N_{0}+N_{a d}}=\frac{50}{100+67}=0.4=40 \% \text {. }
$$

The price of this share shall constitute:

$V_{n s}=p_{o} N_{n}=\mathrm{Sh}_{\mathrm{n}} \times V_{E A}=1.5 \times 67=0.4 \times 250=100$ a.v.

Accordingly, the share of the old shareholders shall be equal to: $1-0.4=0.6$, and its price shall be equal to:

$$
V_{f s}=p_{o}\left(N_{o}+N_{f_{s}}\right)=\left(1-S h_{n}\right) \times V_{E A}=1.5 \times 100=0.6 \times 250=150 \mathrm{a} . \mathrm{v} .
$$

(price of the sum of shares is equal to the price of the $100 \%$ share $=250$ a.v.)

2. Let us now assume that shareholders plan to increase the price of their shares up to 1.75 a.v. per share. In this case the number of shares necessary for the additional issue should be determined using (39):

$$
N_{a d}=\frac{\left(p_{0}-p_{f i n}\right) N_{0}+M \frac{R O E_{n}}{r_{e n}}}{p_{f i n}}=\frac{(1,5-1,75) \cdot 100+50 \cdot\left(\frac{0,3}{0,15}\right)}{1,75}=42,857 \approx 43 .
$$

The price of purchase by the new shareholders of additionally issued shares in this case should constitute 50 (a.v.)/ $43=1.16$ a.v.

In this scenario the price of one share after the additional issue shall constitute:

$p_{\text {fin }}=V_{E A} /\left(N_{o}+N_{a d}\right)=250 /(100+43)=1.75$ a.v.

(taking into consideration the measure of inaccuracy of the $N_{n}$ definition), meaning that it will rise up to the target value.

Now that we know the quantity of shares received by the new shareholders let us determine their share and value.

According to (11) the share of the new shareholders shall constitute:

$$
S h_{n}=\frac{N_{a d}}{N_{0}+N_{a d}}=\frac{43}{100+43}=0.3=30 \% \text {. }
$$

The value of this share shall constitute:

$$
V_{n s}=p_{f i n} \times N_{a d}=S h_{n} \times V_{E A}=1.75 \times 43=0.3 \times 250=75 \text { a.v. }
$$

Accordingly, the share of the old shareholders shall be equal to $1-0.3=0.7$, and its price shall be equal to:

$$
V_{f s}=p_{f i n} \times N_{o}=\left(1-\mathrm{Sh}_{\mathrm{n}}\right) \times V_{E A}=1.75 \times 100=0.7 \times 250=175 \text { a.v } .
$$


(the price of the sum of shares is equal to the price of the $100 \%$ share $=250$ a.v.).

The above example clearly demonstrates the capabilities and limitations of manipulations with the volume of issued shares.

\section{Evaluation of the equity capital upon issue of debt obligations}

During the process of additional issue of shares the company's capital structure is changed: the share of equity capital is increased (with the amount of debt obligations remaining the same), or, otherwise speaking, the share of debt obligations is reduced. The contrary takes place when the company performs issue of debt obligations or redeems a debt: the share of debt in the structure of its capital is changed. Let us analyze in more detail the possible means of evaluation of equity capital with considerable changes to debt obligations. Below you will find several typical situations representing the respective calculation methods.

1. If it is expected that the company's capital structure will change once due to debt growth, and from the evaluation moment $t_{0}$ to moment $t_{1}$ the company will have no interest-bearing debt, the evaluation could be performed using the following procedure:

$$
\begin{aligned}
& V_{E}=V_{E}\left(t_{o}, t_{1}\right)+V\left(t_{1}, \infty\right)= \\
& =\sum_{i=1}^{t 1} \frac{F C F E_{i}}{\left(1+r_{e}\right)^{i-0.5}}+\frac{\sum_{i=t 1+1}^{\infty} \frac{F C F F_{i}}{(1+W A C C)^{i-0.5}}-\operatorname{Debt}\left(t_{1}\right)}{(1+i)^{t 1}},
\end{aligned}
$$

where

$V_{E}$ - the equity capital value of the company,

$V_{E}\left(t_{0}, t_{1}\right)$ - the equity capital value of the company formed from shareholders' cash flow or the $\left(\mathrm{t}_{0}-\mathrm{t}_{1}\right)$ period,

$V_{E}\left(t_{1}, \infty\right)$ - the price of the equity capital of the company formed from shareholders' cash flow after the $\mathrm{t}_{1}$ period,

$t_{1}$ - the moment of time when the shareholders incur a debt in the amount of $\operatorname{Debt}(t 1)$,

$r_{e}$-the expenses on raising shareholders' capital,

$W A C C$ - the nominal weighted average cost of capital after the moment of $\mathrm{t}_{1}$ when the active debt of the company is expected to be at level $\operatorname{Debt}(t 1)$,

$I$ - the expected inflation level for the $\left(t_{0}, t_{1}\right)$ period,

FCFE $i$ - Free Cash Flow to Equity - the volume of cash flow of the company's shareholders in the i period,

$F C F F i$ - Free Cash Flow to Firm - the volume of nominal cash flow of the company's shareholders and borrowers in the i period.

2. If it is expected that the company's capital structure will change once due to debt growth, and from the evaluation moment t0 to moment t1 the company's debt will constitute Debt1, and at moment $t 1$ it will be equal to Debt2, the evaluation could be performed using the following procedure:

$$
\begin{aligned}
& V_{E}=V_{E}\left(t_{o}, t_{1}\right)+V_{E}\left(t_{1}, \infty\right)= \\
& =\sum_{i=1}^{t 1} \frac{F C F F_{i}}{\left(1+W A C C_{1}\right)^{i-0.5}}-\text { Debt }_{1}+\frac{\sum_{i=t+1+1}^{\infty} \frac{F C F F_{i}}{\left(1+W A C C_{2}\right)^{i-0.5}}-\text { Debt }_{2}}{(1+i)^{t 1}}
\end{aligned}
$$


where

$W A C C_{1}$ - the weighted average cost of capital with debt volume at $D e b t_{1}$,

$W A C C_{2}$ - the weighted average cost of capital with debt volume at Debt $_{2}$.

3. If it is expected that the structure of the company's capital will change twice due to debt growth, and from the evaluation moment $t_{0}$ to moment $t_{1}$ the company will have no interest-bearing debt, at moment $t_{1}$ the company will raise debt obligations for the amount of $\boldsymbol{D e b t}_{\mathbf{l}}$, and at moment $t_{2}$ the amount of interest-bearing debt shall be equal to Debt $_{2}$, the evaluation could be performed using the following procedure:

$$
\begin{aligned}
& V_{E}=V_{E}\left(t_{o}, t_{1}\right)+V_{E}\left(t_{1}, t_{2}\right)+V_{E}\left(t_{2}, \infty\right)= \\
& =\sum_{i=1}^{t 1} \frac{F C F E_{i}}{\left(1+r_{e}\right)^{i-0.5}}+\frac{\sum_{i=t l+1}^{t 2} \frac{F C F F_{i}}{\left(1+W A C C_{1}\right)^{i-0.5}}-D e b t_{1}}{\left(1+i_{1}\right)^{t 1}}+\frac{\sum_{i=t 2+1}^{\infty} \frac{F C F F_{i}}{\left(1+W A C C_{2}\right)^{i-0.5}}-\text { Debt }_{2}}{\left(1+i_{1}\right)^{t 1}\left(1+i_{2}\right)^{t 2-t 1}},
\end{aligned}
$$

where

$V_{E}\left(t_{1}, t_{2}\right)$ - the equity capital value of the company constituted from the shareholders' cash flow for the $t_{i}-t_{2}$ period,

$t_{2}$ - the moment of time when the interest-bearing debt of the shareholders constitutes Debt2,

$i_{I}$ - the expected inflation level for the $\left(t_{0}, t_{1}\right)$ period,

$i_{2}$ - the expected inflation level for the $\left(t_{1}, \mathrm{t}_{2}\right)$ period,

$W A C C_{1}$ - the average weighted cost of capital with debt volume at $D e b t_{1}$,

$W A C C_{2}$ - the average weighted cost of capital with debt volume at Debt $_{2}$.

The results of this work are:

\section{RESULTS}

- the theoretical methods for evaluating changes in the value of one share as a result of additional issue of shares;

- new methods for assessing the proportion of shareholders' participation in the capital of companies;

- the methodology of calculation of value per share during the additional issue of shares, based on the discounted cash flow method, and added shareholder value;

- methodology for valuing equity when debt issuance.

If during the additional issue of shares cash is raised in the amount of $M$, then according to (37) the market value of one share of the company in the general case can change, and it will remain unchanged only if the following condition is met ${ }^{20}$ :

$$
\frac{M}{N_{a d}} \times \frac{R O E_{n}}{r_{e n}}=p_{o} .
$$

In all other cases the price of one share will change.

If raised assets are not cash, their market value in the general case will differ from the investment value determined using component value $\left(R O E_{n} / r_{e n}\right)$. This is why investment of non-monetary assets (performed via contribution into the charter and added capital of the due

\footnotetext{
${ }^{20}$ This follows from equation (37).
} 
volume of such assets) usually changes the price of one share. The price of one share may remain unchanged only if the market value of non-monetary assets is equal to their investment cost, which is achieved with component value $\left(R O E_{n} / r_{e n}\right)$ being equal to "one" or in cases, in which evaluation of market value of the non-monetary asset is performed exclusively on the basis of the income approach taking into consideration the component value $\left(R O E_{n} / r_{e n}\right)$.

Taking into consideration the opportunity for investment of cash its investment value ${ }^{21}$ may differ from the current market value (which is equal to its nominal value), determined without considering such opportunities. Thus, everything depends on what is meant under the market price of shares - their price determined without taking into consideration the influence of consequences of the planned additional issue or taking into consideration these consequences. If the decision to make the additional issue has been adopted and will be brought into life in the near future, from the economic point of view the consequences of the additional issue should be considered (unless the market has absorbed them already). The proposed methodology in this paper make it possible to consider it.

Another moment that should be noted is the impact of information about the planned additional issue on the current value of the already issued shares ${ }^{22}$. Since information regarding the planned additional issue cannot spread immediately and market operators have asymmetric information regarding this matter, the quotes of the previously placed shares may change: by leaps and bounds at first (depending on the awareness level of the most informed investors and their interpretation of the related information), and more smoothly afterwards (depending on the dominating interpretation of this information by the market participants) during the whole period from the moment the issuer publishes the respective announcement and up to the moment the additional shares are issued and placed.

\section{DISCUSSION}

Taking into consideration the fact that conditions of functioning of the issuing company, the quantity of shares thereof and the shareholders themselves undergo changes during the period of issue and placement of additional shares, it is pretty difficult to make a definitive conclusion on correlation between the price of placement of new shares and price of previously issued shares for a particular moment of time. When additional shares are issued by an issuer the shares of which are not listed on the stock exchange, no casual observer can say for sure how the price of placement of new shares correlates with the price of previously issued shares ${ }^{23}$.

When performing additional issue by an issuer the shares of which are listed on the stock exchange, prices (and quotes) of previously placed shares are adjusted in the period from the moment of announcement of the future additional issue and up to its actual effectuation. Thus,

\footnotetext{
${ }^{21}$ According to International Valuation Standards (see IVS-2011 principles), investment value is the price of an asset that is being considered as a separate investment or intended for use in operational purposes for its owner or future owner thereof (International Valuation Standards, 2011).

22 "Tail wagging the dog" one may think and he would be absolutely right: indeed, future expectations often determine the present. This is the very basis of the discounted cash flow method and of the income approach. George Soros took another step forward in this direction and created the reflexivity theory according to which the price of shares is determined by prevalent expectations of majority of participants of the market - note.

${ }^{23}$ Since any evaluation has a degree of subjectivity to it, it is always possible to say that one of the two things could happen during evaluation of non-listed shares for the purposes of the additional issue: "calculated price of a single share in the package of newly placed shares was adjusted to the price of a single share in the previously issued package of shares" or "calculated price of a single share in the previously issued package of shares was adjusted during evaluation to the expected price of placement of a single share belonging to the package of the additionally issued shares".
} 
by the moment the additional issue is carried out, the current market prices of the previously issued shares have already actually absorbed (into themselves) its impact.

Considering the mentioned factors it is possible to make a conclusion that practical accounting of possible changes in share prices with an expected additional issue of shares or debt needs to be taken into consideration in the following cases:

- A major issue of non-listed shares is contemplated, and the expected return on the invested funds received from the additional issue differs from the expected expenses for raising additional equity capital;

- There are reasons to believe that raising funds from new shareholders will allow to substantially change the return on previously placed shareholders' capital;

- A major issue of listed shares is contemplated, but only insiders know about it (i.e. when there has been no respective official announcement yet and the evaluation should be made at that moment);

- A considerable issue of debt obligations is contemplated;

- It is necessary to justify the decision to invest in other companies;

- It is necessary to evaluate the distribution of profits from change in the capital structure between the "old" and the "new" shareholders.

In cases of evaluation of listed shares for the purposes of additional issue as of the date prior to which a respective official announcement was made by the issuer (and there is little time left before the moment of placement) the evaluator should rely upon the respective market share quotes ${ }^{24}$.

One should also take into consideration that if volume of the additional issue is comparable to or exceeds the value of previously placed assets, the traditional method of discounted cash flow cannot be used in the income approach - instead one should apply the method of adjusted present value.

The author would like to point out that this article does not provide a decisive answer about conditions of preferability of application of the suggested methodology in comparison with the method of adjusted present value (APV): the terms of application of the suggested calculation method (primarily, as regards the volume of issue) appear to be somewhat blurred. According to the author, on this account there are no precise boundaries of applicability and preferability of the mentioned evaluation methods, however, according to the information available to the author as of the moment of preparation of this article the APV method has been more actively used in evaluations connected with considerable shifts in companies' capital structure (perhaps due to the fact that other methods taking into account the special aspects of additional issue of shares were not well developed).

\section{References}

Brealey R., Myers S. (2004), Principles of Corporate Finance. M. «Olimp-Business».

Copeland T., Koller T., Murrin K. (2005), Measuring and Managing the Value of Companies, 3rd Edition, M. «Olimp-Business».

Damodaran, A. (1994), Damodaran on Valuation, John Wiley and Sons, New York.

\footnotetext{
${ }^{24}$ Taking into consideration (or not taking into consideration) the effects connected with the owners of the evaluated package of shares having (or lacking) elements of control and the degree of liquidity of these shares. 
Kozyr, Y. V. (2017). Overview Of Additional Issue Of Shares And Debt In The Process Of Value Appraisal Of Shares And Planning Of Additional Issue Parameters. Archives of Business Research, 5(2), 102-125

Ferris. K., Petitt B.P. Valuation: Avoiding the Winner's Curse. Williams publishing. Moscow - Saint Petersburg Kiev, 2003.

Fernandez, P. Valuing Companies by Cash Flow Discounting: Fundamental relationships and unnecessary complications. IESE Business School, University of Navarra. Madrid, Spain. November 17, 2015.

Fernandez, P. (2004), "The value of tax shields is NOT equal to the present value of tax shields", Journal of Financial Economics, Vol. 73/1 (July), pp. 145-165.

Fernandez, P. (2007), “A More Realistic Valuation: APV and WACC with constant book value ratio", Journal of Applied Finance, Fall/Winter, Vol.17 No 2, pp.13-20.

Harris, R.S. and J.J. Pringle, (1985), “Risk-Adjusted Discount Rates Extensions form the Average-Risk Case”, Journal of Financial Research (Fall), pp. 237-244.

International Valuation Standards 2011. International Valuation Standards Committee. Authentic translation to Russian. M. Russian Society of Appraisers, 2013.

Kozyr Yu.V. Influence of the planned additional issue of shares on the valuation of current price of a company. Journal «Securities market» (RCB) No 7-8, 2007.

Miles, J.A. and J.R. Ezzel (1980), "The Weighted Average Cost of Capital, Perfect Capital Markets and Project Life: A Clarification", Journal of Financial and Quantitative Analysis (September), pp.719-730.

Miles, J.A. and J.R. Ezzel (1985), “Reequationing Tax Shield Valuation: A Note”, Journal of Finance, Vol. XL, 5 (December), pp.1485-1492.

Myers, S.C. (1974), "Interactions of Corporate Financing and Investment Decisions - Implications for Capital Budgeting", Journal of Finance (March), pp.1-25. 